\title{
Kemajuan Pemasaran Produk Dalam Memanfaatkan Media Sosial Di Era Digital
}

\author{
Ade Onny Siagian', Rini Martiwi ${ }^{2}$, Natal Indra ${ }^{3}$ \\ ${ }^{123}$ Universitas Bina Sarana Informatika, Email:ade.aoy@bsi.ac.id
}

\begin{abstract}
Abstrak Penelitian ini menggunakan pendekatan kualitatif deskriptif dengan tujuan untuk mengetahui media sosial apa yang selalu digunakan dan manfaatnya terhadap pemasaran produk yang terdapat di media sosial. Teknik pengumpulan data melalui kuesioner. Populasi adalah siswa kelas XI dan XII SMK Negeri 22 Jakarta jurusan pemasaran. Hasil temuan menunjukkan Media sosial paling banyak digunakan untuk pemasaran produk adalah Instagram 78\%, Youtube 58\%, Facebook $31 \%$, Whatsapp 20\%, Line 18\%, Path $7 \%$ dan Twitter $2 \%$. Media sosial telah sangat membantu siswa bahkan juga masyarakat dan para pengusaha dalam mempromosikan produk. Dengan hal ini terbukti banyaknya pengguna media sosial memberikan manfaat yang baik dalam hal pemasaran produk. Semakin majunya perkembangan teknologi bahkan dengan adanya media sosial membuat masyarakat khususnya pengusaha dapat menjangkau calon pembeli dengan mudah
\end{abstract}

Kata kunci : Media Sosial; Inovasi; Pemasaran Internet

Abstract. This research uses a descriptive qualitative approach. The objected was to find out what is the social media is always used and its benefits to the marketing products. Data collection techniques using questionnaires. The population is grade XI and XII students of SMK Negeri 22 Jakarta majoring in marketing. The findings show that the social media that used the most widely for marketing products are Instagram 78\%, Youtube 58\%, Facebook 31\%, Whatsapp 20\%, Line 18\%, Path 7\% and Twitter $2 \%$. Social media has greatly helped students and even the community and entrepreneurs in promoting products. The social media users were provides good benefits in terms of product marketing. The more rapid development of technology even with the presence of social media makes the community, especially entrepreneurs, can reach potential buyers easily

Keywords: Social Media; Innovation; Internet Marketing

\section{A. PENDAHULUAN}

Kemajuan teknologi di era saat ini banyak berpengaruh kepada komunikasi maupun informasi yang semula konvensional menjadi modern dan serba digital, membuat semakin pesatnya perkembangan teknologi. Apalagi dengan adanya fasilitas internet yang sudah ada disetiap telepon seluler membuat manusia lebih mudah untuk mengetahui informasi dimanapun dan kapanpun.

Indonesia merupakan negara yang besar dengan jumlah penduduk sekitar 200 juta, sehingga Indonesia disebut sebagai pasar potensial digital. Berdasarkan polling, "kuantitas pemakai internet di Indonesia hidup sekitar 10,12 persen". Namun, menurut Henri, "dari 
jumlah komunitas sebanyak 171,17 juta jiwa sekitar 64,8 persen yang sudah tersambung ke internet". Jumlah itupun diperkirakan dapat terus bertambah.

Dalam situs internet Kaskus mengklaim bahwa jumlah transaksi mencapai Rp. 575 Miliar perbulan, dan diantara situs ojual beli online lainnya yaitu Tokopedia meraup 14 triliun setiap bulan, Bukalapak 13 triliun, dan juga shopee yang mencatat angka fantastis, meraup 59 triliun rupiah hanya dalam waktu satu semester ( 6 bulan) di 2018. Belum lagi para pelaku jual beli online melalui media social (social media) yang saat ini menjadi media paling ampuh untuk dijadikan media pemasaran. Berdasarkan survey Asosiasi E-Commerce Indonesia (idEA), transaksi online melalui media social seperti facebook dan Instagram mencapai posisi $60 \%$, kaskus $14 \%$, twitter $12 \%$ dan media social lainnya.

Social media sejatinya memang sebagai interaksi dan alat sosialisasi, serta bisa juga dijadikan fasilitas sebagai alat pemasaran yang paling murah dan gampang.

Kemudahan kebutuhan urusan kita menjadi bagian dari kemajuan media sosial, apabila disandingkan efek yang lain maka media sosial akan berdampak pada semua lini, kemudian berbeda pula dengan pemasaran secara tradisional, Pemanfaatan media teknologi melalui pemasaran merupakan terobosan yang perlu dievaluasi. Media sosial dimengerti atau tidak mulai saat ini telah banyak dipergunakan oleh berbagai kelompok kelompok publik, sehingga penelitian ini eksperimen mengurai dan menganalisa kebutuhan dan sebagai alat media sosial dalam konteks pemasaran.

\section{B. KAJIAN LITERATUR}

\section{Media Sosial}

"Media sosial menurut Philip Kotler dan Kevin Keller (2012;568) dalam (Fauzi , Februari 2016), merupakan sarana bagi konsumen untuk berbagi informasi teks, gambar, audio, dan video dengan satu sama lain dan dengan perusahaan dan sebaliknya. Peran media sosial semakin diakui dalam mendongkrak kinerja bisnis". "Media sosial memungkinkan bisnis kecil dapat mengubah cara berkomunikasi dengan pelanggan, memasarkan produk dan jasa serta saling berinteraksi dengan pelanggan yang bertujuan untuk membangun hubungan yang baik. Abdullah (2012: 32) menyatakan jika sebuah merek/produk akan diluncurkan, maka media sosial digunakan untuk menyebarkan informasi yang sifatnya membuat teman atau pengikutnya menjadi penasaran".

\section{Inovasi}

"Menurut Kotler dan Keller (2009) dalam ( Sinurat, 2017) inovasi adalah produk, jasa, ide, dan persepsi yang baru dari seseorang. Inovasi adalah produk atau jasa yang dipersepsikan oleh konsumen sebagai produk atau jasa baru. Secara sederhana, inovasi dapat diartikan sebagai terobosan yang berkaitan dengan produkproduk baru. Namun Kotler menambahkan bahwa inovasi tidak hanya terbatas pada pengembangan produk-produk atau jasa-jasa baru. Inovasi juga termasuk pada pemikiran bisnis baru dan proses baru. Inovasi juga dipandang sebagai mekanisme perusahaan untuk beradaptasi terhadap lingkungan yang dinamis".

\section{Pemasaran Internet}

Menurut (Asriani, 2011) "Sistem pemasaran melalui internet (internet marketing) merupakan salah satu bentuk kemajuan teknologi yang memungkinkan terwujudnya one-onone marketing, dimana konsumen bisa berinteraksi secara langsung, real time, dan dua arah 
(interaktif) dengan perusahaan yang menjual produk atau jasanya". "Blythe (2000:229) mengatakan karakteristik dari internet sebagai sebuah alat pemasaran dapat dilihat dari : 1 . Gaya komunikasi. Gaya komunikasi pada internet lebih interaktif dan langsung (berlangsung cepat) atau tidak langsung (ada perbedaan waktu antara pesan dan umpan balik). 2. Bersifat sosial. Komunikasi mengambil sebuah peran yang lebih personal. 3. Konsumen bisa mengontrol hubungan. Konsumen mampu untuk mengontrol waktu dan tempat dimana mereka bisa mengakses informasi tersebut, mereka lebih tertarik lagi untuk berpartisipasi dalam proses mendapatkan informasi dari mesin (internet) 4 . Konsumen bisa mengontrol isi pesan. Jika konsumen bisa untuk mengontrol isi pesan, maka komunikasi akan berjalan dengan sangat interaktif".

\section{B. METODOLOGI PENELITIAN}

Penelitian ini memanfaatkan metode penelitian kualitatif, dengan pendekatan deskriptif yaitu menganalisa sumber data dengan cara mendeksripsikan data yang telah terkumpul agar dapat dibuat kesimpulan yang berlaku untuk umum.

Objek penelitian pada SMK Negeri 22 Jakarta, periode penelitian tanggal 23 September - 30 September 2019. Populasi penelitian adalah siswa kelas XI dan XII jurusan pemasaran sebanyak 54 siswa. Pengumpulan data yang dipakai dalam penelitian yaitu kuesioner. Kuesioner terdapat 36 pertanyaan. Penyusunan kuesioner dengan skala likert dengan alternative jawaban yang diberikan "sangat setuju", "setuju", "ragu-ragu", "tidak setuju", dan "sangat tidak setuju". Tipe jawbannnya berupa check list.

\section{HASIL DAN PEMBAHASAN}

Hasil data intensitas akses media sosial untuk pemasaran dilihat dengan hitungan jam/hari dalam setiap produksi. Ada 5 interval waktu yang ditanyakan kepada koresponden dalam penggunan media sosial sebagai pemasaran. Interval tersebut yaitu; >1jam; 1-2 jam; 3-4 jam; 4-5 jam; dan <5 jam.

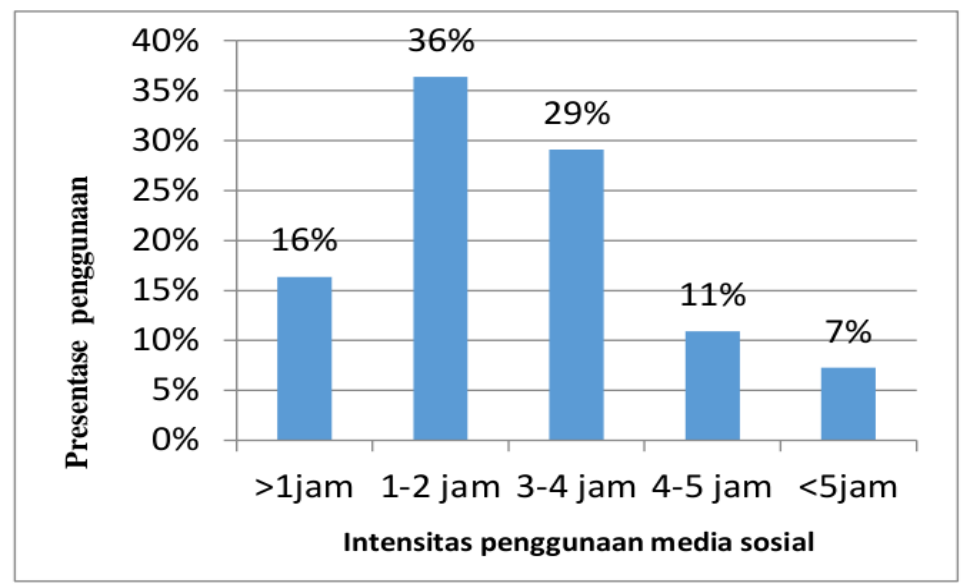

Gambar 1. Diagram Batang Intensitas Pengunaan Media Sosial untuk Pemasaran Produk

Hasil data menunjukkan bahwa media sosial yang digunakan oleh siswa SMK Negeri 22 Jakarta sebagai alat pemasaran produk ada 7 jenis media sosial yaitu Instagram, 
ISSN NO. (PRINT) 2598-0823, (ONLINE) 2598-2893

Youtube, Facebook, Whatsapp, Line, Path dan Twitter. Hasil presentase dapat dilihat pada gambar 2.

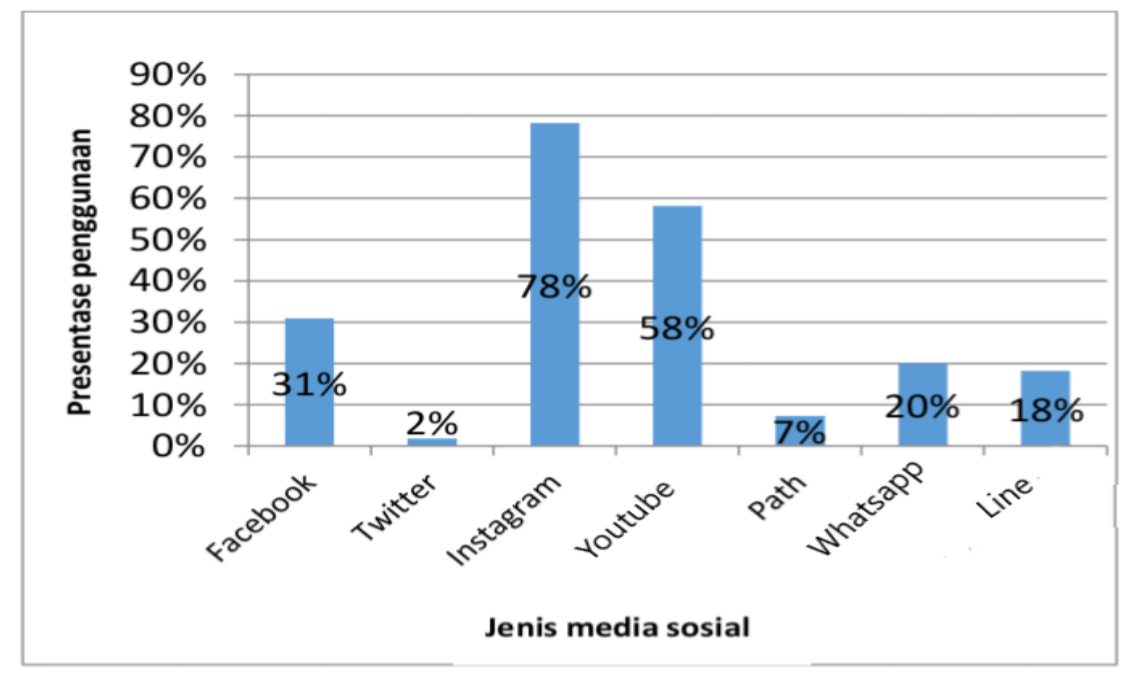

Gambar 2. Media sosial yang digunakan untuk pemasaran

Hasil data dari peran media sosial bagi siswa jurusan Pemasaran SMK Negeri 22 Jakarta dalam mempromosikan produk dilihat dari saegi manfaat media sosial sebagai alat pemasaran. Adapun hasil presentase dapat dilihat pada gambar 3.

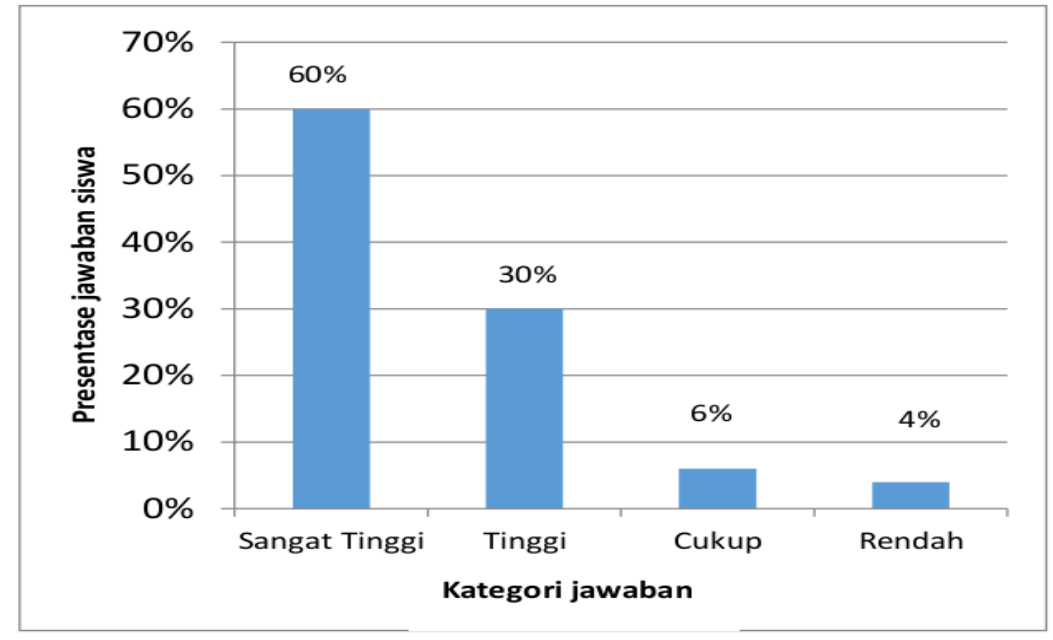

Gambar 3. Peran media sosial dalam mempromosikan produk

Intensitas Pengunaan Media Sosial dalam Pemasaran Produk 
Mayoritas siswa menghabiskan 1-2 jam waktunya untuk memasarkan produk melalui media sosial, sehingga bias disimpulkan wajtu tersebut adalah waktu yang palig efektif. Waktu ini dianggap cukup untuk memperlihatkan keterbaruan informasi produk dan memberikan uman balik yang cepat kepada khalayak.

\section{Media Sosial yang digunakan sebagai Alat Pemasaran}

Media sosial yang digunakan oleh siswa untuk memasarkan produk adalah Instagram (78\%), Youtube (58\%), Facebook (31\%), Line (20\%), whatsapp (18\%), Path $(7 \%)$, dan Twitter (2\%). Instagram adalah media yang paling sering digunakan untuk pemasaran produk. Instagram merupakan media yang paling pas sebagai alat dalam pemasaran produk dengan video dan foto. Instagram mengizinkan pengguna mengambil video dan foto, memakai penyaring digital dan membagikannya sehingga orang lain bisa melihat foto dan video yang kita bagikan. Pengeditan foto atau video yang bagus dan aestethic juga sangat berpegaruh karena lebih bagus dan menarik dilihat sehingga memungkinkan calon pembeli yang melihat langsung tertarik untuk membeli produk tersebut. Instagram juga menyediakan tulisan pada setiap foto yang kita unggah hingga 2200 karakter sehingga informasi atau promosi dapat tersampaikan dengan jelas.

Sesuai dengan penelitian yang dilakukan oleh Gumilar (2015:81) "pengunaan Instagram sebagai media sosial yang ramai digunakan disebabkan fitur-fitur yang paling banyak digunakan oleh aplikasi tersebut sangat mendukung promosi karena berbasiskan gambar/foto dan video".

\section{Peran Media Sosial dalam Mempromosikan Produk}

Media sosial berperan bagi siswa dalam mempromosikan produk. Siswa sudah menggunakan media sosial dengan maksimal. Mean yang didapatkan adalah sebesar 31,75 yang termasuk dalam kategori sangat tinggi.

\section{Sub Indikator Membangun Merk}

Hasil dari ini dikategorikan cukup tinggi. Hal ini membuktikan bahwa media sosial juga efektif dalam memperkenalkan produk ke khalayak. Siswa SMK Negeri 22 Jakarta yang menggunakan media sosial untuk memperkenalkan produknya mengaku media sosial sangat berperan dalam memperkenalkan produknya ke calon konsumen.

\section{Sub Indikator Publisitas}

Publisitas merupakan cara siswa untuk membagikan informasi kepada pelanggan mengenai produknya. Dalam hal ini diketahui siswa telah melakukan publisitas produknya melalui media sosial dengan sangat efektif. Pelanggan dapat mengetahui informasi mengenai produk yang dipromosikan dengan mudah karena telah tersedia didalam akun yang dibuat oleh siswa. Hal ini selaras dengan penelitian sebelumnya yang dilakukan oleh Faraz dan Zohaib (2012:10) Publisitas melalui media sosial membantu calon pembeli lebih mengenali produk yang ditawarkan oleh produsen. Publisitas penting bagi perusahaan agar pembeli dapat dengan mengetahui informasi tentang detail produk serta cara pembeliannya. 
Sub Indikator Riset Pasar

Sub indikator ini membahas terkait peran media sosial untuk memahami sifat dan kebutuhan konsumen. Sub indikator ini termasuk pada kategori yang tinggi artinya siswa dapat melakukan riset pasar dengan baik melalui media sosial. Riset pasar bertujuan untuk memahami sifat dan kebutuhan pasar sehingga inovasi produk akan tepat sasaran dan mudah dijual. Hal ini sesuai dengan pendapat Puntoadi (2011:21) bahwa media sosial memberikan pelanggan kesempatan untuk berinteraksi lebih dekat, dalam bentuk penawaran komunikasi lebih individual. Melalui media sosial rata rata kebiasaan konsumen dapat diketahui oleh pemasar dan dapat dilakukan interaksi secara individu serta membentuk ketertarikan lebih dalam.

\section{E. KESIMPULAN}

Kesimpulan

Siswa SMK Negeri 22 Jakarta telah memanfaatkan media sosial sebagai alat pemasaran produk dengan Intensitas penggunaan 1-2 jam sebanyak 36\%. Dengan intensitas 3-4 jam 29\%, kurang dari 1 jam sebanyak 16\%. Penggunaan $4-5$ jam ada $11 \%$ dan siswa paling sedikit mnjawat $>5$ jam yaitu sebanyak \%. Medial sosial yang digunakan untu pemasaran produk adalah Instagram 78\%, Youtube 58\%, Facebook 31\%, Whatsapp $20 \%$, Line 18\%, Path 7\% dan Twitter $2 \%$. Media sosial telah sangat membantu siswa bahkan juga masyarakat dan para pengusaha dalam mempromosikan produk. Dengan hal ini terbukti banyaknya pengguna media sosial menyebabkan pengaruh yang baik dalam hal pemasaran produk. Semakin majunya perkembangan teknologi bahkan dengan adanya media sosial membuat masyarakat khususnya pengusaha dapat menjangkau calon pembeli dengan mudah. Cukup dengan memanfaatkan media sosial sebagai media pemasaran pengusaha akan lebih efektif dalam melakukan promosi, membangun merek, dan membangun hubungan dengan calon pembeli. Sesuai dengan pernyataan menurut Gunelius dan susan (2011:10) pemasaran media social memiliki tujuan untuk (1) membangun relasi misalnya faedah terbaik dan dari pemasaran media sosial adalah kapabilitas untuk membangun relasi dengan pelanggan secara aktif. (2) membuat merek misalnya diskusi melalui media sosial menyajikan bagaimana cara sempurna untuk menambah brand awareness, memajukan pengenalan dan ingatan akan label atau merek dan menaikkan loyalitas merek. (3) Pemberitaan misalnya (Market)pemasaran melalui media sosial mencadangkan outlet di mana industri dapat berbagi informasi penting dan mengkonversi persepsi negatif. Menurut Basu Swastha (1999: 246), publisitas atau Pemberitaan adalah "beberapa informasi tentang barang, sasaran, atau organisasi yang disiarkan ke publik melalui media tanpa adanya tarif biaya atau tanpa kontrol dari sponsor". Pemberitaan merupakan aksesori yang efektif bagi 
alat promosi yang lain seperti periklanan, personal selling, dan promo penjualan. Biasanya, media bersedia mempublisitas suatu cerita apabila materinya dirasakan cukup menarik atau patut dijadikan berita. (4) Promosi misalnya melewati pemasaran media sosial, memberikan potongan harga eksklusif dan kesempatan untuk audiens untuk membuat orang-orang mencoba untuk dihargai dan secara khusus, serta agar memenuhi harapan jangka pendek.

\section{Saran}

Untuk para siswa diharapkan dapat mengolah dan mengembangkan kemampuan pemasaran melalui media sosial agar produk yang diciptakan dapat terus berkemang. Dan sekolah harus mendukung segala kegiatan siswanya dan mengembangkan usaha yang telat dibangun walau masih dibangku sekolah. Gurupun harus membimbing siswa dalam menggunakan media sosial dengan bijak karena apa yang dilakukan siswa sangat baik dan dapat memotivasi banyak orang khususnya orang yang ingin memiliki usaha tapi bingung untuk memasarkannya. Dengan memanfaatkan media sosial merupakan hal bagus dan patut dicontoh untuk terus menyebar luaskan informasi produk, menjangkau lebih banyak konsumen, dan dapat mengembangkan merek.

Untuk masyarakat diharapkan dapat menggunakan media sosial dengan hal yang positif seperti memasarkan produk dan membagikan informasi yang positif. Karena dengan adanya media sosial ini apalagi banyak sekali penggunanya, membuat banyak peluang khususnya untuk kegiatan pemasaran produk.para pengusaha juga harus siap bersaing dalam memasarkan produknya di media sosial untuk itu kreatifitas dalam melakukan promosi dimedia sosial yang menerik dan terlihat beda dengan yang lain itu sangat penting agar banyak pengguna media sosial yang menjadi calon pembeli saat melihat promosi yang sudah dilakukan.

\section{DAFTAR PUSTAKA}

Asriani, A. (2011). Pemanfaatan Internet Marketing dalam Pemsarana Produk Unggulan Pertanian Provinsi Gorontalo. Jurnal Komunikasi KAREBA No. 3 Vol. 1 , 249 - 257.

Gumilar, G. (2015). Pemanfaatan Instagram Sebagai Sarana Promosi Oleh Pengelola Industri Kreatif Fashion Di Kota Bandung, Jurnal IImu Politik dan Komunikasi, V (2).

Gunelius, S. (2011). Social Media Marketing. United States: McGraw- Hill Companies.

Fauzi , V. P. (Februari 2016). Pemanfaatan Instagram Sebagai Social Media Marketing ErCorner Boutique Dalam Membangun Brand Awareness Di Kota Pekanbaru. JOM FISIP Vol. 3 No. 1, 1 - 15.

Kotler and Armstrong. (2006). Prinsip-prinsip Pemasaran, jilid 1 edisi 12. Jakarta: Erlangga. Kotler and Armstrong. (2009). Prinsip-prinsip Pemasaran, jilid 2 edisi 13. Jakarta: Erlangga Kusumo, R. (2012). Pengaruh Media Sosial Terhadap Customer Retention (Studi Kasus Pada J.Co), Jurnal Manajemen Pemasaran Universitas Indonesia. 
Lesmana, R. (2015). analisis strategi pemasaran untuk meningkatkan penjualan perumahan green river city bekasi (study kasus di pt. artha bangun pratama) (Doctoral dissertation, Universitas Pamulang).

Newman, W L. (1997). Metode Penelitian Sosial Pendekatan kualitatif dan Kuantitatif. Boston: Allyn \& Bacon

Nurian, L. (2016). Aktifitas Promosi Mikharisti Tampubolon. Strategi Promosi Coffee Shop Melalui Media Sosial Instagram (Studi Deskriptif Pada Akun @Crematology), eProceeding of Management: 3 (2): 2421.

Sinurat, E. M. (2017). Pengaruh Inovasi Produk, Harga, Citra Merek Dan Kualitas Pelayanan Terhadap Loyalitas Pelanggan Mobil Suzuki Ertiga. Jurnal EMBA Vol.5 No.2 Juni 2017, Hal. 2230 - 2239, 2230 - 2239.

Sunardi, N., Hamsinah, H., Sarwani, S., Rusilowati, U., \& Marjohan, M. (2020). Manajemen Pengelolaan Budidaya Ikan Laut (Sea Farming) Untuk Meningkatkan Pendapatan Masyarakat di Kepulauan Seribu, DKI Jakarta. Jurnal Abdi Masyarakat Humanis, 1(2).

Sugiyono. (2016). Metode Penelitian. Bandung: ALFABETA.

Widyaningrum, E.D. (2012). Strategi Pemasaran Kampung Batik Laweyan Solo, Jurnal Manajemen Pemasaran Universitas Indonesia.

Wibowo, H. (2015). Analisis Strategi Pemasaran Untuk Meningkatkan Daya Saing Umkm (Studi Pada Batik Diajeng Solo), Jurnal Administrasi Bisnis (JAB), 29 (1): 59-66.Jumlah pengguna internet di Indonesia tembus 171 Juta Jiwa, Kompas.com Geoffrey Scott, D. A. R. C. M. (2013). Sustainability Accounting, Management and Policy Journal. Sustainability Accounting, Management and Policy Journal, 4(3), 264-284. https://doi.org/10.1108/SAMPJ-09-2013-0037 